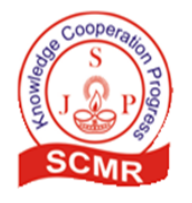

\title{
An Analysis of Cropping Pattern and Crop Combination Regions of Thiruvarur District (2011-2016), Tamilnadu, India
}

\author{
S.Geetha* and R. Maniyosai", \\ *Asst. Professor of Geography, Govt. College for Women (A), Kumbakonam \\ ${ }^{\#}$ Asst. Professor of Geography, Govt. Arts College (A), Kumbakonam
}

(Received 30 September, 2019: accepted 4 January, 2020)

https://doi.org/10.36224/ijes.120404

\begin{abstract}
India is an Agricultural Nation. Its primary occupation is Agriculture. Today, India ranks second worldwide in farm output. Agriculture and allied sectors like forestry and fisheries accounted for $13.75 \%$ of the GDP in 2013, about $50 \%$ of the workforce. The crops are generally grown in combination and a particular crop occupies a position of total isolation from other crops. The studies of crop combination regions constitute an important aspect of agricultural geography as it provides a good basis for agricultural regeneration. Through different regions may have different climate and soil conditions. But each region is Individual to crops. For a comprehensive and better understanding of agricultural system the study of crop combination is of great significances and is essential for agricultural planning. The present study enlights to the crop combinations in Thiruvarur District. Agricultural Geography is very need for rural planning, because high density of population and increasing annual growth rate of population. It is necessary to producer cultivate more crops in the same field. So diversification and suitable combination of crops with short duration is necessary for an increase in the production. The study of crop combination is also helpful for the study of the comprehensive area development planning particularly for the rural areas.
\end{abstract}

Key words: crop combination, crop diversification, maximum deviation, minimum deviation

\section{Introduction}

The study of cropping pattern constitutes an important aspect of agricultural geography as it provides a good basis for agricultural regionalization. The crops occupies a position of total isolation other crops in a given area at a given time. The physical factors determine the shape of the areas of crop combination is also helpful for the study of the comprehensive area development planning particularly for the rural areas. The importance of adoption of suitable cropping patterns in a developing country like India cannot be overemphasized. The horizontal expansion of agriculture is not possible without heavy capital investments. Only judicious utilization of land by adopting more remunerative cropping patterns scientific rotation of crops and multiple cropping may help in overcoming the food and raw material problems of the country.

\subsection{Aim}

The aim of the study is to find out the cropping pattern of Thiruvarur District. 


\subsection{Objectives}

- To study about the cropping patterns, crop concentration and crop diversification methods in Thiruvarur district.

- To calculate the weaver's minimum deviation method in the district.

\subsection{Study area}

Thiruvarur District lies between 10o20'and 11 o 07' North latitude and 79 o 15' and 79 o 45', East longitude. The total area of the district is 2,377 sq.km. Nannilam, Kudavasal, Needamangalam, Mannargudi, Thirutturaippoondi, Valangaiman, and Thiruvarur are the Seven Taluks of this district (Figure 1). Thiruvarur lies in the Cauvery River basin and the main occupation of the inhabitants of the town and surrounding regions is agriculture. More than $70 \%$ of the workforce is involved in agriculture; $14 \%$ being cultivators and rest are agricultural laborers.

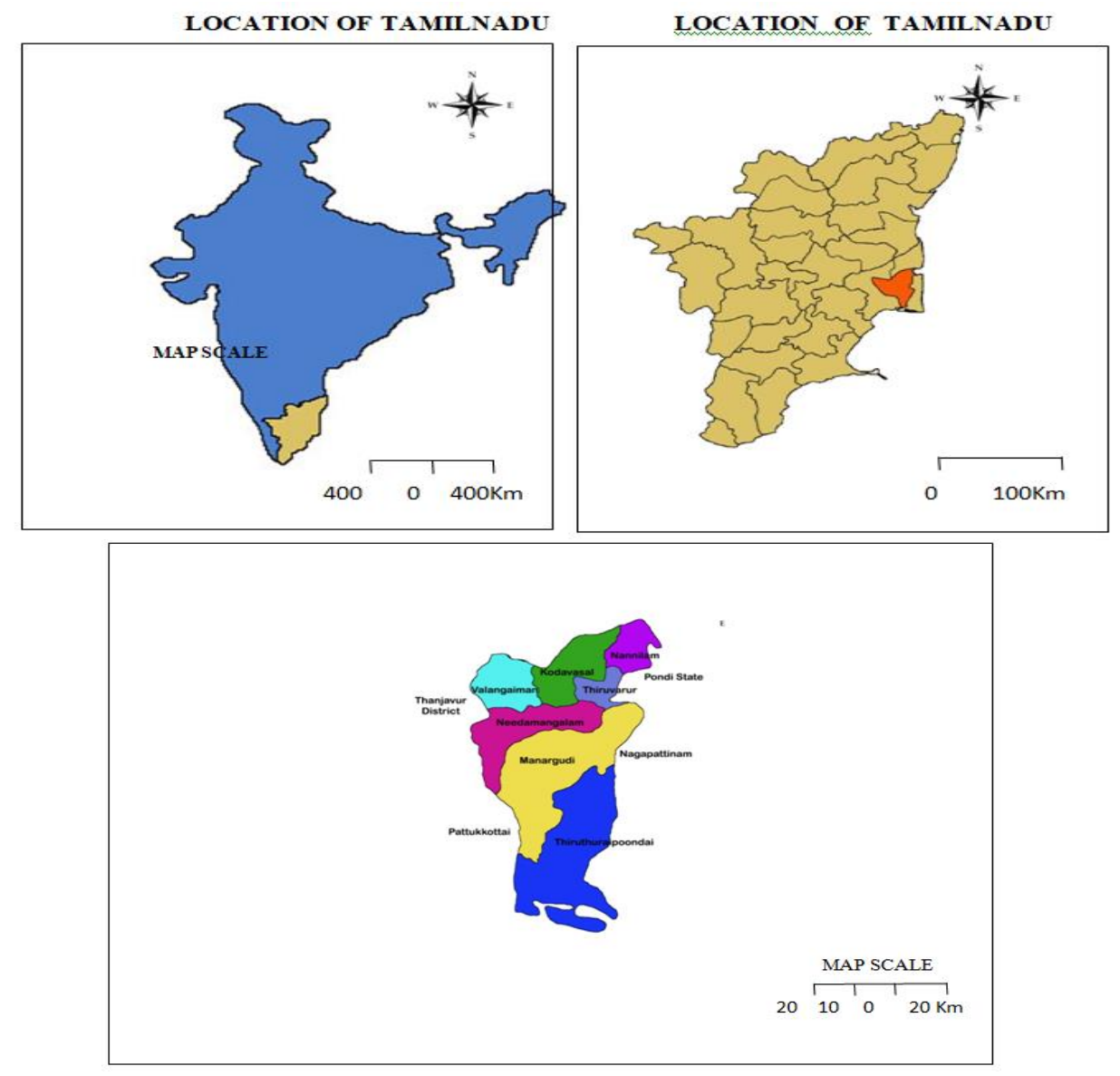

Figure 1: Location map of Thiruvarur district

\section{Methodology}

In the present study fully based on secondary sources of data are used. Source of data include existing maps, text books, internet websites, newspapers, Journals and others. The cropping data 
for 5 years (2011- 2016) have been collected for 7 Taluks which are located in Thiruvarur District. Agricultural data have been collected from the Thiruvarur statistical office.

\subsection{Review of literature}

According to weaver (1954) was the first to use statistical techniques to establish the crop combination of the Middle West (USA). Scott (1957), Bennett (1961) Coppock(1964) and Dois (1959) have also been contributed in the same fields. Khan (1982) presented a management model which consider all the important components of an irrigated system and may help to maintain a permanent irrigated agriculture. Mai et al. (1984) developed a suitable cropping schedule for rabi season in Debra block in Midnapore district using Lp. They suggested paddy, mustard and potato to be grown under lifi irrigation without canal supply for achieving maximum benefit.

Hence, the present study discusses about the cropping patterns, crop concentration, crop diversification, weaver's minimum deviation method, Doi's method and Rafiullah maximum positive deviation method in Thiruvarur district

\subsection{Cropping pattern in Thiruvarur district}

Though the district experiences many crops, 8 crops are being cultivated throughout the district. The major four crops i.e. cotton; Gingelly, coconut and Ground nut are clubbed into others.

There are quite a large variety of crops with varying hectares under cultivation. During the year of 2011 to 2016 paddies, Black gram, Sugar crop, Cotton, Gingelly, coconut and Ground nut are selected for the study. Accordingly Paddy, Black gram, Green gram, Sugar crop, Cotton and others are the major crops which accounts for $87.05 \%, 2.65 \%, 8.44 \%, 10.09 \%, 1.33 \%$ of the total cropped area of the district respectively.

The Black gram is the second important crops which are about $9.16 \%$ to $21.34 \%$ in all Taluks. After the harvest of paddy, Black gram is grown. All the taluks cultivate Black gram in more than $10 \%$ of their total cropped area. The Green gram is Third important crops which is about (26.94\%-8.44\%) in the taluk. The area under Ground nut cultivated in entire district. The ground nut distributed more in Mannargudi, Needamangalam, Thiruthuraipoondi and Thiruvarur Taluks.

\subsection{Crop concentration in Thiruvarur district}

Crop concentration means the variations in the density of any crop in an area/region at a given point of time. The concentration of a crop in an area largely depends on its terrain, temperature, moisture and pedological conditions. Each crop has a maximum, minimum and optimum temperature. It has a tendency to have high concentration in the areas of ideal agro climatic conditions and the density declines as the geographical conditions become less conductive (Majid Hussain, 1996). The percentage share of a crop in the total cropped area and the determination of relative density with the help of location quotient are some of the techniques that are frequently used for the detraction of crop concentration regions.

$$
\text { Cropping Intensity }=\frac{\frac{\sum a i j}{\sum a i o}}{\frac{N i}{N o}} \times 100
$$


If the index value is greater than unity, the component areal unit accounts for a share greater than it would have had if the distribution were uniform in the entire region and therefore, the areal unit has a concentration of great agricultural significance. After ascertaining the index values for the crops in the component areal units, the percentage share of each crop is calculated and then the areal units that show concentration are put in an ascending or descending order.

If the index value is greater than unity, the component areal unit accounts for a share greater than it would have had if the distribution were uniform in the entire region and therefore, the areal unit has a concentration of great agricultural significance. After ascertaining the index values for the crops in the component areal units, the percentage share of each crop is calculated and then the areal units that show concentration are put in an ascending or descending order.

The index scale is calculated by dividing array into equal parts to distinguish the high, medium, and low concentrations in Thiruvarur district which has been shown in figure (3.2). Thiruvarur district has $73 \%$ of the area available for cultivation of which net sown area is only $55 \%$. A number of crops are grown in the district on account of the varying climatic conditions, topography, soil and irrigation facilities. The cropping pattern and crop combination varies from one place to another place in the district.

In order to find out the concentration of the district, the crop details for period of five years (2011-2016) have been arrive at which more than one percent of the total cropped area for a particular crop has been considered for the study.

Accordingly there are crops such as Paddy, Black gram, Green gram, Sugar crop, Cotton, coconut, Gingilley and Ground nut, which shares more than one percent of the total cropped area of the district. Among the crops paddy and sugar crop wet crops and others are dry crops.

The concentration of each crop is brought under three classes' i.e. high, medium and low concentration. This index of crop concentration has the advantages of understanding the area of specialization.

\subsubsection{Paddy}

Paddy is important crop in the study area; Nannilam, kodavasal, mannargudi, Needamangalam, Thiruthuraipoondi, Thiruvarur and valangaiman are major producers of paddy. High concentrations of paddy seen in Valangaiman and Thiruthuraipoondi taluks. Medium concentration found in kodavasal, Nannilam, Needamangalam and Thiruvarur Taluks.

\subsubsection{Black Gram}

Blackgram is another major important crop in the study area, Black gram is highly concentrated in Mannargudi, Thiruvarur and Needamangalam. The moderate concentration is seen in Thiruthuraipoondi taluk. The lowest concentration of Black gram present in Valangaiman, Nannilam and Kodavasal. 


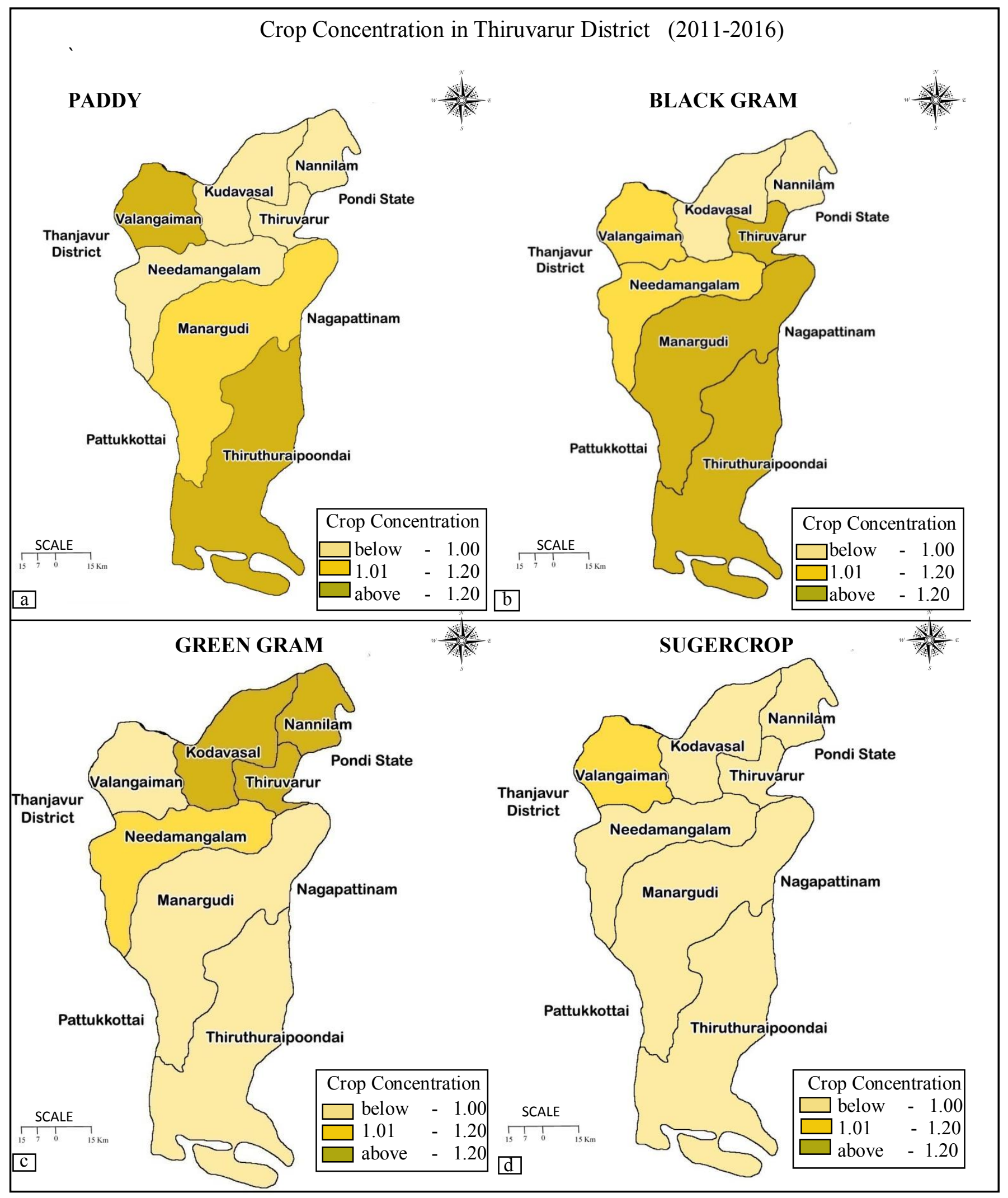

Figure 2: Crop concentration 


\subsubsection{Green gram}

Green gram is another major important crop in the study area; Nannilam, kodavasal and Thiruvarur are having the major concentrations of Green gram. Medium concentration only found in Needamangalam, low concentration of green gram seen in Mannargudi, Thiruthuraipoondi and Valangaiman taluks.

\subsubsection{Sugar crop}

Sugar crop is important crop in the study area; the crop concentration analysis indicates the high concentration found in Valangaiman. Moderate concentration were found in Kodavasal, Mannargudi, Nannilam and Needamangalam. The lowest sugar crops were concentrated in Thirurthuraipoondi and Thiruvarur.

\subsection{Crop diversification methods}

Crop diversification patterns like that of crop concentration, have great relevance in the agricultural land use planning. The diversification of cropping patterns means raising a variety of crops for arable land, the keener the competition the higher the magnitude of diversification (Majid Hussain,1996). Looking at the importance of crop diversification many geographers have developed techniques for the measurements of crop diversification and crop specialization.

For the measurements of crop diversification Bhatia (1965) developed a formula based on the grass cropped area. The formula has been expressed as:

$$
\text { Index of crop diversification }=\frac{\text { Percent of sown area under } \mathrm{x} \text { crops }}{\text { Number of crops }}
$$

Where $\mathrm{x}$ crops are those crops that individually occupy 10 percent or more of the gross cropped area in the area under study. In this method, higher the value of the diversification index lower is the degree of crop diversification and vice versa. The value that comes in between these two diversification would be considered as medium. By this method crop diversification index have been found out for each taluk in the District. This gives an idea of how many taluks are having high and low diversification of crops and thus laying path for the study of crop combination. If there is high diversification naturally there is a possibility of different crops grown in that particular area. Thus, it gives basic knowledge for the crop combination(Majid Hussain,1996)..

As the major wet and dry crops such as Paddy, Black gram, Green gram, Sugar crop, Cotton, Gingelly, coconut and Ground nut showed only their distribution of concentration in the district. The high diversity of crops is shown in the taluks of Nannilam, kodavasal, and Thiruthuraipoondi. The low diversity of crops are seen in the taluks of Nannilam, valangaiman and Needamanalam. Medium diversity of crops are distributed only in Mannarkudi taluk. The Table 3.3 shows the crop diversification patterns in the district. 
Table 1: Crop diversification index of thiruvarur district (2011-2016)

\begin{tabular}{|c|c|c|c|c|c|c|c|c|c|c|}
\hline S.No & Taluks & Paddy & $\begin{array}{c}\text { Black } \\
\text { Gram }\end{array}$ & $\begin{array}{c}\text { Green } \\
\text { Gram }\end{array}$ & $\begin{array}{c}\text { Sugar } \\
\text { Crop }\end{array}$ & Cotton & Gingilley & Coconut & $\begin{array}{c}\text { Ground } \\
\text { Nut }\end{array}$ & $\begin{array}{c}\text { Index } \\
\text { Value }\end{array}$ \\
\hline 1. & Nannilam & 57.26 & 10.05 & 26.94 & 0.26 & 5.09 & 0.01 & 0.35 & - & 14.28 \\
\hline 2. & Kodavasal & 62.59 & 9.16 & 25.33 & 0.08 & 1.80 & 0.09 & 0.91 & - & 14.28 \\
\hline 3. & Mannargudi & 71.39 & 19.70 & 4.62 & 0.06 & 1.93 & 0.26 & 1.00 & 2.94 & 12.75 \\
\hline 4. & Needamangalam & 66.66 & 16.80 & 14.80 & 0.04 & 1.16 & 0.06 & 0.26 & 0.18 & 12.49 \\
\hline 5. & Thiruthuraipoondi & 70.00 & 21.34 & 5.00 & 1.06 & - & 0.05 & 3.57 & 0.01 & 14.43 \\
\hline 6. & Thiruvarur & 61.26 & 17.55 & 20.39 & 0.13 & 0.077 & 0.06 & 0.071 & 0.43 & 12.49 \\
\hline 7. & Valangaiman & 87.05 & 2.65 & 8.44 & 0.09 & 1.33 & 0.10 & 0.31 & - & 14.28 \\
\hline
\end{tabular}

Crop diversification in Thiruvarur district (2011-2016)

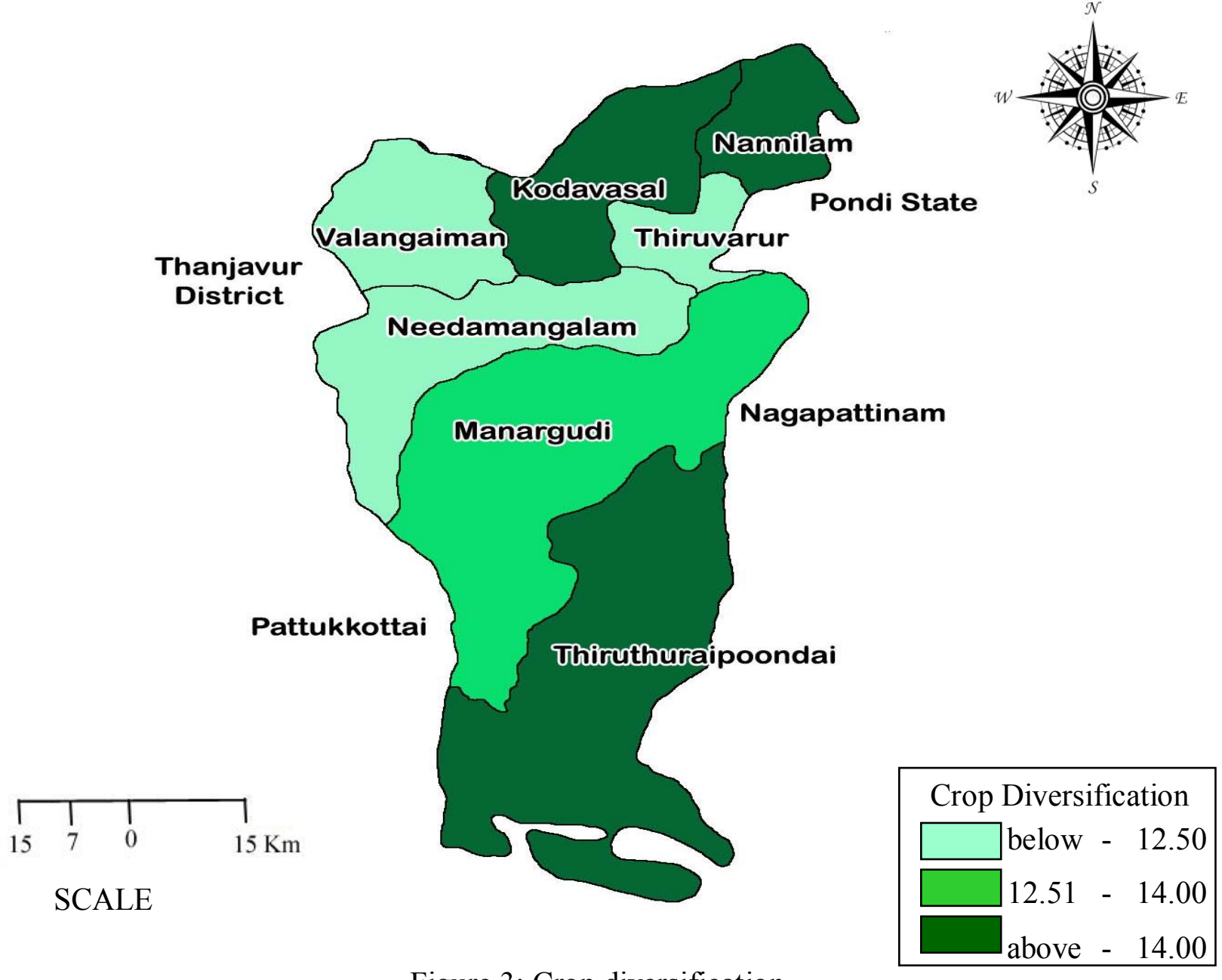

Figure 3: Crop diversification 


\subsection{Crop combination by Weaver's method}

The study of crop combination is also helpful for the study of comprehensive area development planning particularly for the rural areas. In the field of agricultural geography weaver's (1954) was the first to use statistical technique to establish the crop combination of the middle west(USA).

In his work weaver deviation of the real percentages of crops (occupying over 1 percent of the cropped area) for all the possible combinations in the component areal units against a theoretical standard. For the determination of the minimum deviation the standard deviation method was used

$$
S D=\frac{\sqrt{\sum d^{2}}}{n}
$$

Weaver's minimum deviation method has been applied for each taluk in the district considering first 8 ranking crops and accurate crop combination have been found out (Table 2). In Thiruvarur district used this technique at the taluk level for the period of 2011-2016 and identified eight crop combination in the district which has been plotted in Figure 3

Monoculture or one crop combination is not found in Thiruvarur district. In this district, two crop, three crop, seven crop, 8 crop combination have identified during the year 2011-2016. Paddy cultivated throughout the year. 3 crops per year due to the availability or fertile soil and irrigation facilities.

The two crop combinations are found in valangaiman taluk. The three crop combination is found in three taluks such as Nannilam, Kudavasal and Thiruthuraipoondi. The seven crop combination is found Needamangalam taluk only. The eight crop combinations are identified in two taluks such as mannargudi and thiruvarur.

It is clear found that the cropping pattern of the district is influenced by the physical as well as socio-economic factors of the study region. There are numerous ways in which the present cropping pattern could be improved. The marginal lands could be used by bringing them under cultivation. In the same way fertilizer should be used for the poor soil to improve the fertility.

Table 2: Weaver's minimum deviation method Thiruvarur district (2011 - 2016)

\begin{tabular}{|c|l|c|l|}
\hline S. No & \multicolumn{1}{|c|}{ Taluks } & $\begin{array}{c}\text { No of Crop } \\
\text { Combination }\end{array}$ & \multicolumn{1}{c|}{ Name of the Crop } \\
\hline 1. & Nannilam & 3 & Paddy, Green gram, Black gram \\
\hline 2. & Kudavasal & 3 & Paddy, Green gram, Black gram \\
\hline 3. & Mannargudi & 8 & $\begin{array}{l}\text { Paddy, Green gram, Black gram, Ground nut, } \\
\text { Cotton, Coconut, Gingelly }\end{array}$ \\
\hline 4. & Needamangalam & 7 & $\begin{array}{l}\text { Paddy, Green gram, Black gram, Cotton, Coconut, } \\
\text { Ground nut, Gingelly }\end{array}$ \\
\hline 5. & Thiruthuraipoondi & 3 & Paddy, Green gram, Black gram \\
\hline 6. & Thiruvarur & 8 & $\begin{array}{l}\text { Paddy, Black gram, Green gram, Ground nut, } \\
\text { Cotton, Coconut, Gingelly, Sugar crop }\end{array}$ \\
\hline 7. & Valangaiman & 2 & Paddy, Green gram \\
\hline
\end{tabular}


Crop combination region weaver's method in Thiruvarur district (2011-2016)
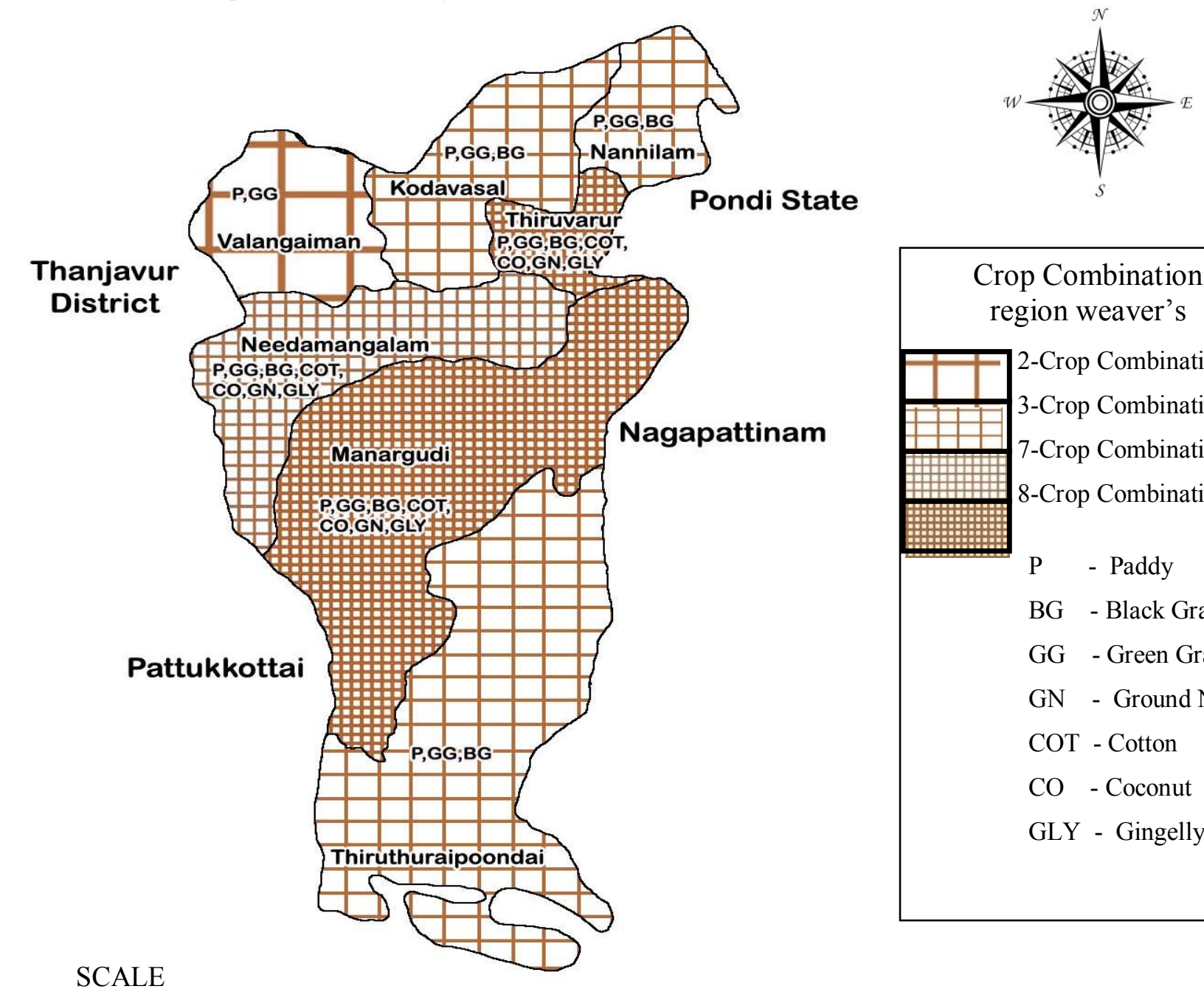

\begin{tabular}{|l} 
Crop Combination \\
region weaver's \\
3-Crop Combination \\
3-Crop Combination \\
7-Crop Combination \\
8-Crop Combination \\
P \\
BG - Paddy \\
GG - Green Gram \\
GN - Ground Nut \\
COT - Cotton \\
CO - Coconut \\
GLY - Gingelly \\
\end{tabular}

Figure 4: Crop combination region

\section{Conclusion}

Changing of cropping pattern increasing the Agricultural productivity. The climate of the District is fairly healthy, though hot and relaxing. A fairy health climate exists throughout the year. The Vennar and Vettar rivers play an important role in draining the district. The ranking of crops shows that eight crops such as Paddy, Black gram, Green gram, Sugar crop, Cotton, coconut, Gingilley and Ground nut are cultivated as primary crops. Paddy is cultivated as major crop in throughout the district. According to Weavers method of analysis there are 2,3,7 and 8 crop combination regions in Thiruvarur District. The analysis shows that there is no diversification of cropping pattern in most of the taluks of Thiruvarur District. The cropping pattern has influenced by the terrain, climate and socio economic factors. The cropping pattern gives knowledge to agricultural practice and selection of crop by farmers. 


\section{References}

1. Bhatia S.S., An index of crop Diversification, professional geographer, 1960, 12(2), 3-4

2. Lakshminarayana, V. and Rajagopal, S. P., Optimum cropping pattern for basins in India, Journal of Irrigation and Drainage Engineering, ASCE,1997, 103, 53-70

3. Najmal Islam Hashmi, Pattern of crop concentration and Diversification in upper Ganga, Yamuna Doab, International Journal of Innovative Research 2, 2012, 1(5), 481-496

4. Punithavathi, J.S. Tamilenthi and R. Baskaran, Agricultural concentration and crop wise changes in Thanjavur District, Tamil Nadu, Using Geographical Information system, International Multidisciplinary Research journal, 2012, 2(7): 44-48

5. Ramasudaram, K. Banukumar, p. Alaguraja, D. Yuvaraj, S.R. Nagarathinam, A study on crop combination regions in Tamil Nadu, India Using map into and GIS, Int. Journal of Advances in Remote sensing and GIS, 2012, 1, 1-7

6. Yuvaraj, R.M., Principle crop concentration In Cauvery Basic Region of Tamil Nadu, India ground of Applied Research, 2014, 4(10), 239-292 